\title{
Importance and Performance Analysis of the Solid Waste ManagementSystem in Tomohon City, Indonesia
}

\author{
Festus Evly R.I. Liow ${ }^{1.2}$, Achmad Wicaksono ${ }^{1.3}$, Zetly E. Tamod ${ }^{1.4}$, Soemarno ${ }^{1.5}$ \\ ${ }^{I}$ Doctoral Program of Environment and Development Studies, Graduate School, University of Brawijaya, Indonesia; \\ ${ }^{2}$ Department of Industrial Engineering, Faculty of Technology Industry, Institute Technology of Minaesa, Indonesia; \\ ${ }^{3}$ Department of Civil Engineering, Faculty of Engineering, University of Brawijaya, Indonesia; \\ ${ }^{4}$ Department of Soil Sciences, Faculty of Agriculture, University of Sam Ratulangi, Indonesia; \\ ${ }^{5}$ Department of Soil Sciences, Faculty of Agriculture, University of Brawijaya, Indonesia.
}

\begin{abstract}
Nowadays amount of solid wastes are increasing very fast. Accumulation of urban solid wastes is not balanced in perspective of good environmental management. Therefore, the study of urban solid wastes management system and the participation of urban communities in solid wastes management is needed. This study aimed to analyze level of importance and performance of the existing solid wastes management system, urban communities' participation, and relationship between urban community perception and their participation in existing system of solid waste management in Tomohon City. Scientific methodes in data analysis are the Importance Performance Analysis (IPA), The Chougill's ladder for participation level, and the Product-Moment correlation.Results of research suggested that existing waste management aspects that are on the first quadrant (as the main priority), consist of (a) lack of cleanliness of the solid wastes collection sites, (b) the limited numbers of the solid wastes collection sites, (c) time schedule for solid wates collection which is done on 2-3 days interval, (d) the fewer numbers of solid waste supervisor, and (e) the response to public complaints should be intensified in improving any public services in relation to solid wastes management. Results of community participation analysis based on Chougill 's ladder shows that community role in solid wastes management is in the phase of conspiracy (1.68), the community action is in the phase of peace (3.12), community motivation is in the phase of information (2.0), and community responsibility is in the phase of information (1.86). The relation between community perception $(X)$ and community participation $(Y)$ is statistically significant $(r=0.983)$. It is concluded that "community participation" in solid wastes management is significantly determined by their "perception".
\end{abstract}

Keywords: Importance Performance Analysis, Perception, Participation, Solid Wastes Management.

\section{Introduction}

The excessive production of urban solid wastes have resulted in degradation of environmental quality and environmental pollution. Moreover, the uncomprehensive handling of the waste will trigger social problem, like clashes between residents, riot, the blockade of garbage landfills facility (Hadi, 2004). Urban population growth gives great effects on wastes volume that are produced by people. Waste produced by the urban communities in Tomohon city have resulted in any negative impacts. The accumulation of garbages can be seen on urban main roads and local access roads, vacant land, and urban drainage channels, in fact it can be seen also at the "Beriman"market location as the main shopping center in Tomohon city.

At present, various problems were encountered in implementing the good waste management such as economic, social, cultural and technological applicationconstraints (Nuryani, 2003). To achieve the condition of the people who live healthy and prosperous in the future, it will be necessary to have a healthy living environment. From the aspect of waste, the word healthy means a condition that would be achieved if the waste can be managed well, so that it is clean from the neighborhoodswhere people indulge in it (Public Work MinistryDecree no: 21/PRT/M2006).

In theory, to solve the garbage problem has required a shift in approach from the end-pipe approach to the source approach. With the source approach, then the waste is handled in upstream before it gets to the endof waste treatment facility (downstream) (Syafrudin, 2006). In principle,the source approach requires reduction of waste products that will be sent to the final processing. The Way that can be taken to reduce waste, such as waste separation and application of the 3R principles (Reduce, Reuse, Recycle)(Syafrudin, 2006). Urban settlements are the biggest waste producers, approximately $60-70 \%$ of total waste generation (Kustiah, 2005).The Indonesia Act Number 23, 1997 on Environment, Article 16 mandates that the public be responsible as a producer of waste. It is expected that the community,as a source of generation at risk as a source of pollutants, to participate in the waste management system (Syafrudin, 2006).

Waste management problems become very serious in urban areas due to the complex problems faced and the high population density, so waste management is often prioritized its handling in urban areas (Sudrajat, 2006). The problems that often arise in handling municipal solid waste that accumulate continually are high 
operating costs and the difficulty of proper space for disposal, so that the handling of municipal solid waste is often a bad impact on the environment (Himawanto, dkk. 2010). In addition, the behavior and lifestyle of the people still tend to leads to an increase in the rate of waste generation that are very burdensome to hygiene management, resource constraints, budget, and vehicles transporting garbage. Population growth continues to increase with an increasingly consumerist lifestyle. It is certainly followed by increased production of waste (Praditya, 2012). One approach to the community to be able to assist the government's program is to familiarize the public on hygiene behavior in accordance with the waste management program, that is changing people's perception of waste management which is done orderly, smooth, and evenly, and changing the habits of people in poor waste management and local social,structure and culture factors (Purnaini, 2011).

In Tomohoncity, the growth of the amount of waste far exceeds from the population growth that is now reaches 95,111 lives. This is a major reason that the problem of waste is a major issue that must be resolved, either in the short, medium, and long term periods. The populationis rissing fast that followed by a growing city activity andcausingan increasing and varied waste/sewage. Services for waste management as well as in public services aimed at serving the community in every waste management's activity. Waste management services require a good performance, where thesystem is running effectively and efficiently, and can give satisfaction to the people. It is very important to know public's perception of solid waste management that is done orderly, smooth, and evenly, the factor oflocal social, structure and culture, also their habits in waste management (Aryenti, 2011). The waste perception is an important thing in waste management system, and understanding the perception can increase the effectiveness of the promotion of waste management (Drackner, 2005).However, it often happens that urban solid waste management becomes ineffective due to limited effort of government, on the financial aspect, personnel number, and the availableequipment.

Preliminary research in waste management based on public perception was conducted by Yogiesti et al (2010) to identify the characteristics of waste and performance of operational in perception and preference of the people in Kediri City by making composter units. Sartika (2010) stated that the implementation of management model has been designed to be very dependent on public attitudes in treating waste. Long-term strategy that involves full public participation in the management of household waste has been initiated by a group of citizens who care about the environment (Surjandari, et al., 2009). In addition,aspects of community participation to waste management prospects to be seen from community's perception is very good to the aesthetic environment as well as involvement in the dissemination to the public (Saribanon, et al., 2009). Also it is necessary to identify the presence of the solid waste system in assessing needs, defining how to design,implementing and monitoring the waste management program that is more effective and sustainable (Katonika, 2009). Nowadays, the public perception is a little bit change which can disrupt the equilibrium level (Isa et al., 2005; Longe and Williams, 2006). However, recent findings suggest that sex differences may influence public perception about waste management (Ehrampoush and Moghadam, 2005; Longe et al, 2009).

This study aimed to (1) analyze the importance and performance of the waste management system that exist today, (2) analyze the level of community's participation in waste management, and (3)analyze the relationship between perception and participation of the community in waste management.

\section{II.1. Research Variable}

\section{Research Method}

1. Importance and performance variables of waste management system and variable of community's perception

The study consisted of four variables, each variable can be defined operationally as follows:

1) Hygiene condition; its indicators are: the cleanliness of main roads, drainage, environmental markets, city parks and shopping areas, and garbage collection sites.

2) Condition of facilities and infrastructure; its indicators are: condition of the garbage collection sites, the volume of garbages, location of the garbage collection site, time schedule for garbage collection, garbage collection tools, number of garbage collection tools, time/frequency of garbage transport, garbage transport equipments.

3) Janitor condition; its indicators are: the quality and quantity of janitor.

4) Government Responses to the garbage service complaints.

\section{Community Participation on Garbage (Solid Wastes) Management}

There are four variables for community participation research:

1) Community's participation; the community sorts out garbage at its sources.

2) Community's action; role of community's activities in environmental hygienes management.

3) Community's motivation; role of the community in garbage management independently.

4) Government response to the complaints of garbage services.

\section{II.2. Data Collection Instrument.}

The research data was obtained from the public as respondents in the five districts with 19,009 households (Anonim,2012). Respondents were visited by investigators completed a questionnaire prepared by first charging the 
description of the filling technically, whereas depth interviews with the the resource persons as solid waste officials in the Department ofSpatial Planning, Landscaping,andSolid Waste Tomohon, waste transport officer and janitor.

The numbers of Sample were determined by the method of Stratified Random Sampling at the level of confidence $90 \%$ and an error that occurred not more than $0.1(10 \%)$. Spread of the sample to obtain data on the respondents conducted by incidental sampling technique by visiting people's homes that have a chance to be distributed the questionnaires. The samples were adjusted by the respondents who by chance visited by researcher. The amount of the required samples were calculated using Slovin formula (Sevilla in Umar, 2003), as the following:

$$
\mathrm{n}=\frac{\mathrm{N}}{\mathrm{Nd}^{2}+1}=\frac{19.009}{\left(19.009 \times(0,1)^{2}\right)+1}=99,48 \text { rounded to }=99 \text { samples }
$$

$\mathrm{n}=$ number of sample, $\mathrm{N}=$ number of population, and $\mathrm{d}=$ degree of accuracy is determined $10 \%$.

To obtain primary data, the data collection technique that used wasby distributing questionnaires.The data were obtained from a questionnaire survey with the question format is expressed in the form of Likert scale tabulation. The Importanceof the waste management system is scored using four levels ofLikert scale, which are very important (4), critical (3), less important (2), and not important (1). The performance of the management system and community's participation is scored using four levels of Likert scale, namely very good/very satisfied (4), Good/satisfied (3),poor/less satisfied (2), and not good/not satisfied (1). Public's perception is scored using four levels of the Likert scale, strongly agree (4), agree (3), less agree (2), disagree (1). Likert scale has been used as a measure the strength of respondent's opinion on the problem of waste management (PageBuchi, 2003; Isaetal, 2005;Uebersax, 2006).

\section{II.3. Data Analysis Method}

\section{Importance and Performance Analysis (IPA) of the waste management system in Tomohon city}

Based on the tabulation, then the attributes were sorted to very desirable (importance) or undesirable at the level of importance in the waste management system, also the performance attributes which itsperformance has been good and which ones need to be improved to enhance the performance of waste management based on public's perception. To answer the problem formulation to the extent of importance and performance level of waste management system in Tomohon City, it is used Importance-Performance Analysis (IPA) wherethe application in a number of settings have been modified(Kitcharoen, 2004) in waste management.

IPA is not only to test the performance of an item but also the importance of the item as a determining factor in the satisfaction orcommunity's assessment to waste management. On the other hand, IPA is a powerful evaluation tool to determine the good attributes and also the attributes that need to be improved which requires immediate action(Wong, et al 2009). IPA displays information related to the service factors that the community think they give great influence to their satisfaction and loyalty, and the service factors according to the public needs to be improved because of the unsatisfactory condition now (Supranto, 2006).

Based on the result of importance and performance level assessment would be produced a calculation of the level of concordance between the level of importance and performance waste management system based on the perception of the community. Level of compliance is the result of a comparison score performance/execution of the score of importance. Compliance level is what will determine the order of priority to improve the factors that influence the level of community's participation in waste management. In this study there are two variables that are represented by the letters $\mathrm{X}$ and $\mathrm{Y} ; \mathrm{X}$ is the level of performance of waste management that will give satisfaction to the people, $\mathrm{Y}$ is the level of community importance to waste management. The formula that has been used :

$\mathrm{Tk}_{\mathrm{i}}=\frac{\mathrm{X}_{\mathrm{i}}}{\mathrm{Y}_{\mathrm{i}}} \times 100 \%$,

$\mathrm{Tki}=$ respondent suitability level, $\mathrm{Xi}=$ performance assessment score, $\mathrm{Yi}=$ importance assessment score

Horizontal axis $(\mathrm{X})$ will be filled by the implementation level score, while the vertical axis ( $\mathrm{Y}$ ) will be filled by the score of importance. In simplifying the formula, then for every factor that affects the waste management system, with the formula:

$$
\bar{X}=\frac{\sum X_{i}}{n} \quad \bar{Y}=\frac{\sum Y_{i}}{n}
$$

$\mathrm{X}=$ Average score of the performance of waste management system, $\mathrm{Y}=$ Average score of the importance of waste management system, $\mathrm{n}=$ respondent number (99)

Cartesian diagram is a building that is divided into four sections bounded by two lines intersecting perpendicular at points $(\mathrm{X}, \mathrm{Y}), \mathrm{X}$ is the mean of the average score of the level of implementation of all the factors or attributes, and $\mathrm{Y}$ is the average of the averagescore of the importance of all the factors that affect the waste management system, with 15 factors or attributes.The next formula: 


$$
\overline{\bar{X}}=\frac{\sum_{i=1}^{N} \bar{X}}{K} \quad \overline{\bar{Y}}=\frac{\sum_{i=1}^{N} \bar{Y}}{K}
$$

$\mathrm{K}=$ the number of attributes/facts that can affect the waste management system $(\mathrm{K}=15)$.

Next, the level of those elements will be explored and divided into four sections to the Cartesian diagram as shown in figure 1 .

\begin{tabular}{|c|c|}
\hline $\begin{array}{c}\text { QUADRANT I } \\
\text { Concentrate Here } \\
\text { High Importance } \\
\text { Low Performance }\end{array}$ & $\begin{array}{c}\text { QUADRANT II } \\
\text { Keep Up the Good Work } \\
\text { High Importance } \\
\text { High Performance }\end{array}$ \\
\hline $\begin{array}{c}\text { QUADRANT III } \\
\text { Low Priority } \\
\text { Low Importance } \\
\text { Low Performance }\end{array}$ & $\begin{array}{c}\text { QUADRANT IV } \\
\text { Possible Overkill } \\
\text { HIgh Performance }\end{array}$ \\
\hline
\end{tabular}

Figure 1.Quadrant Distribution of Importance-Performance Analysis.

Here are explanations for each quadrant in the waste management system:

1) First Quadrant: Top Priority. Items (factors / variables / parameters) that are in this quadrant as perceived by the respondents considered very important but not yet satisfactory for the current state, so it should be a concern for the government to allocate adequate resources.

2) Second quadrant: Maintain Achievement. Items (factors / variables / parameters) that are in this quadrant as perceived by the respondents considered as an additional factor for the public's expectations of the management of waste, so the government must ensure to maintain its performance achievements.

3) Third quadrant: Items (factors / variables / parameters) that are in this quadrant as perceived by the respondents are considered to have a low waste management system at the same time is considered less important by the public, so the government does not need to prioritize these factors.

4) Fourth Quadrant: Overrated. Items (factors / variables / parameters) that are in this quadrant as perceived by the respondents considered less important, so that the government could allocate resources associated with these factors to other factors that are more in need in improving waste management system.

The method of data analysis using SPSS statistical analysis program support version 17, wherein the analysis by simple scatter graphs to form a Cartesian diagram.

\section{Analysis of Community's Participation Level in Waste Management}

This research used scoring analysis for the determination the level of community's participation, analysis Delphi to choose the constraints of community's participation, and analysis triangulation to identify the participation of the community in waste management.

1) Scoring Analysis In Determining Community'sParticipation Level on Waste Management.

This Analysis is usedto know the real situation on the ground with regard to the level of community's participation in waste management to the variable ofcommunity's participation, community action, community's motivation, and community's responsibility. From this analysis is obtained the final result in the form of community's participation level position that will be used as a basic determination strategy to improve waste management.

According to Chougill, 1996 in Setiawan, (2005), the value of public's participation can be grouped into eight, namely: Self-Management with a score of between 1 to 1.38 ; Conspiracy with scores between 1.39 to 1.76; informing with a score of 1.77 to 2.14 , diplomacy with a score of 2.15 to 2.51 ; Pretending (Dissimulation) with score between 2.52 to 2.88; Reconciling (Conciliation) with scores between 2.89 to 3.26 , Partnership with a score of 3.27 up to 3.63, and the last level is empowerment with a score of 3.64 up to 4.00.

2) Delphi Analysis For Choosing Constraints of Public's Participation in Solid Waste Management

On this research, Delphi analysis carried is out directly on 4 (four) variables of participation, namely community's participation, community's action, community's motivation, and community's responsibility, for each internaland external causes from the community. The function of Delphi analysis techniques: (1) To explore the opinions and generate information in determining decisions, (2) To explore the assumptions/ factors underlying certain decisions by searching information needed to reach a consensus, (3) To determine the number of alternative programs / plans, (4) To explore opinions and generate information in decision-making.

3) Triangulation Analysis to identify the Strategies to increase Community's Participation

This study used triangulation analysis to draw a conclusion of the three concepts together, which is based on literature studies, previous research, and empirical conditions to the variable of 
community'sparticipation, community's action, community's motivation, and community's responsibility. These three concepts have a substance which is equivalent associated with efforts to increase community's participation in the waste management.Triangulation made the obtained data in this research became more consistent, thorough and definitely as well as increase the strengthof the data (Sugiyono, 2011).

\section{Relationship between Community Perception and it's Participation in Waste Management.}

The relationship between perceptions and community's participation is analyzed by using the correlation method of product moment. The analyzed data derived from a survey questionnaire included variables for perception, namely 1) the condition of cleanliness, the condition of facilities and infrastructure, 3)the condition of janitor, and 4) response to complaints. The Variables for participation, namely 1) the role of the community, 2) community's action, 3) community's motivation, and 4) community's responsibility.

The formula to calculate the correlation is (Sugiyono, 2011):

$$
r_{x y}=\frac{N\left(\sum x_{i} y_{i}\right)-\left(\left(\sum x_{i}\right)\left(\sum y_{i}\right)\right)}{\sqrt{\left\{n \sum x_{i}^{2}-\left(\sum x_{i}\right)^{2}\right\}\left\{n \sum y_{i}^{2}-\left(\sum y_{i}\right)^{2}\right\}}}
$$

$\mathrm{r}_{\mathrm{xy}}=$ correlation between variable $\mathrm{x}$ and $\mathrm{y}$; $\mathrm{x}=$ the answer score for each perception item; $\mathrm{y}=$ the answer score for each participation item;and $n=$ the number of respondents

The result of this correlation calculation were compared with the figures in the table of test correlation using $1 \%$ confidence level with an error factor of $99 \%$. If the correlation value > correlation table, then the perception will be positively correlated and very real (significant) with the participation of the community. Besides, the testing of the instrument validity used Statistical Software analysis in a computer with SPSS Version 17.0.

\section{III.1. IPA of the Waste Management System}

\section{Results and Discussion}

IPA is a strategic tool that can quickly enable the government plans to understand customer needs and desires (priority areas) and also to assess customer satisfaction rather than just relying on performance indicators (Wong, et al, 2011). Based on data obtained from a survey of 99 respondents using a questionnaire, it can be obtained the average assessment value of importance rate and level of performance according to the janitor, garbage transport officers, waste officers, and the public to waste management system based onTable 1 .

Table 1. Calculation of the average value of importance rate and the performance of Waste

\begin{tabular}{|c|c|c|c|c|c|c|}
\hline No. & $\begin{array}{c}\text { Variables Affecting Waste Management } \\
\text { System in Tomohon City }\end{array}$ & $\begin{array}{l}\text { Performance } \\
\text { Level }\end{array}$ & $\begin{array}{l}\text { Importan } \\
\text { ce Level }\end{array}$ & $\begin{array}{l}\text { Concordance } \\
\text { Level }(\%)\end{array}$ & $\begin{array}{l}\text { Performance } \\
\text { Score } \\
\bar{X}\end{array}$ & $\begin{array}{c}\text { Importance } \\
\text { Score } \\
\bar{Y}\end{array}$ \\
\hline 1. & Main street cleanliness (E1) & 287 & 315 & 91.11 & 2.90 & 3.18 \\
\hline 2. & Drainage cleanliness (E2) & 219 & 306 & 71.57 & 2.21 & 3.09 \\
\hline 3. & $\begin{array}{l}\text { Cleanliness in the market environment, city parks } \\
\text { and shopping areas (E3) }\end{array}$ & 226 & 308 & 73.38 & 2.28 & 3.11 \\
\hline 4. & Cleanliness in temporary solid waste location (E4) & 233 & 327 & 71.25 & 2.35 & 3.30 \\
\hline 5. & Temporary solid waste location condition (E5) & 239 & 306 & 78.10 & 2.41 & 3.09 \\
\hline 6. & Temporary solid waste location numbers (E6) & 227 & 329 & 69.00 & 2.29 & 3.32 \\
\hline 7. & Temporary solid waste location placement (E7) & 235 & 321 & 73.21 & 2.37 & 3.24 \\
\hline 8. & Time garbage collection (E8) & 242 & 338 & 71.60 & 2.44 & 3.41 \\
\hline 9. & Condition collection tool (E9) & 264 & 344 & 76.74 & 2.67 & 3.47 \\
\hline 10. & Numbers of collection tool (E10) & 197 & 319 & 61.76 & 1.99 & 3.22 \\
\hline 11. & Time/frequency of transport (E11) & 290 & 353 & 82.15 & 2.93 & 3.57 \\
\hline 12. & Transportation equipment condition (E12) & 277 & 337 & 82.20 & 2.80 & 3.40 \\
\hline 13. & The quality of janitor (E13) & 274 & 323 & 84.83 & 2.77 & 3.26 \\
\hline 14. & The numbers of janitor (E14) & 236 & 348 & 67.82 & 2.38 & 3.52 \\
\hline 15. & Response to complaints (E15) & 223 & 328 & 67.99 & 2.25 & 3.31 \\
\hline & Average Scores $(\overline{\bar{X}}$ and $\overline{\bar{Y}}$ ) & & & 74.85 & 2.47 & 3.30 \\
\hline
\end{tabular}

In Table 1, the level of respondents on waste management system isthat the average concordance level that respondents desired is $74.85 \%$. This suggests that the expectations and desires of the respondents; waste employees, janitors, garbage transportation officials, and the public to be noted by the government, especially on the number of garbage collection tool $(61.76 \%)$, number of janitors $(67.82 \%)$, the government's response to citizen complaints $(67.99 \%)$ and the number of temporary solid waste location $(69.00 \%)$.

The average score of each of the variables according to Table 1 for the average performance scoreis 2.47 and an average score of importance is 3.30 . 


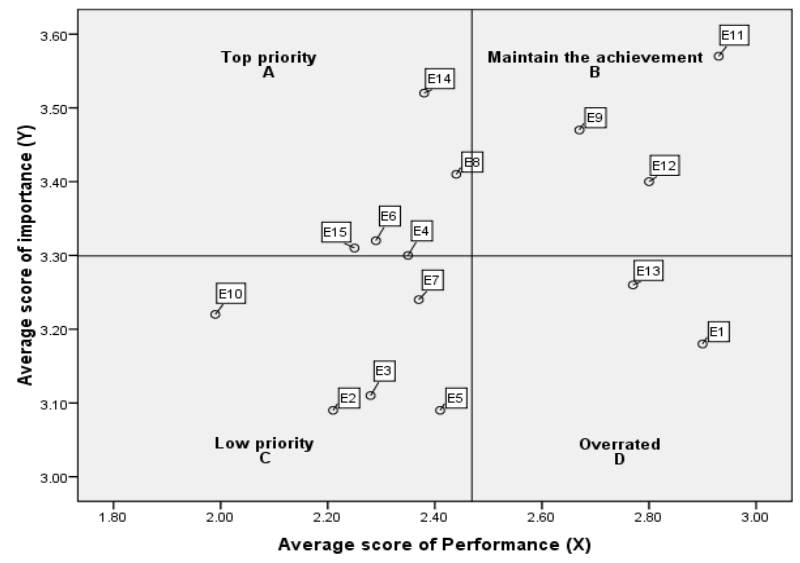

$\mathrm{Y}=$ Average score of importance, $\mathrm{X}=$ Average score of Performance, $\mathrm{A}=$ Top priority, $\mathrm{B}=$ Maintain the achievement, $\mathrm{C}=$ Low priority, $\mathrm{D}=$ Overrated. Description: $\mathrm{E} 1$ to E15 codes refer to Table 1

Figure 2.Importance-Performance Analysis of Waste Management System in Tomohon City

The result of Cartesian diagram in Figure 2, clearly seen the implementation elements of the factors or attributes that affect the condition of the waste management system which is divided into four sections.

The interpretation of the Cartesian diagram can be explained as follows:

1. Quadrant A (High Priority).

It shows the factors or attributes that affect the performance of waste management systems which are in this quadrant, and handling needs to be prioritized by the government, because the presence of these factors were considered very important by the community including the janitor, and the attendant waste, while the level of implementation is still not satisfactory to the public. The factors which are included in quadrant A:

a. The condition of the temporary solid waste location isless clean, thus affecting the performance of the transport of waste (E4).

b. Less numbers of temporary solid waste location (E6).

c. Garbage collection time, from field observations, is implemented from two to three days a week, except for the shopping area thatisdone every day (E8).

d. The numbers of janitor, from the interviews in residential area, mostly just doing garbage collection on protocol streets and most places with rotational system (E14).

e. Response to public complaints is a form of service in order to improve the performance of waste management (E15).

2. Quadrant B (maintain the achievement)

This showed the factors or attributes that affect the public's willingness to waste management system which are in this quadrantneed to be maintained, because generally the level of implementation is in accordance with the importance and expectation of the community, so it can satisfy the public. The factors which are included in quadrant B:

a. The condition of collection tools are quite good and have not got damage that can disturb garbage collection activity. There are 4 garbage vehicles that are still new (E9).

b. Time/frequency of transport, as much as 2-3 times a day and transport of waste is done since the dawn, morning, afternoon until late evening (E11).

c. The garbage conveyances, either Arm Roll Truck or Dump Truck were aged less than 10 years and regularly carried out the improvement by Department of Tarumansa Tomohon (E12).

3. Quadrant C (low priority)

This suggests that the factors that affect the condition of waste management system in this quadrant is still considered to be less important to the customer, while the quality of the implementation is normal or sufficient alone. The factors which are included in quadrant $\mathrm{C}$ :

a. From the field observation, drainage is used as the waste disposal sites, so it madethe drainage unclean. The indication of that case, the drainage in the road pavement in Walian One Village often get clogged when rain volume is high(E2).

b. The condition of market environment, city parks and shopping areas, from the observation were still many piled up and scattered garbage. Under these conditions, it can be concluded the performance of the waste management in the market is still not optimal (E3).

c. Temporary solid waste location condition, based on the field observation, often found in damaged condition(E5).

d. Temporary solid waste location placement is not appropriate designation on the main roads in the city of Tomohon(E7). 
e. From the observations and interviews with the residents, many areas were unserved waste service evenly, especially with a narrow location, because the number of garbage collection tools are still lacking (E10).

4. Quadrant D (overrated)

This Suggest that the factors that influence the waste management system in this quadrant considered excessive in its execution, this is mainly due to the condition of waste management system which is not very important to the existence of such factors, but the implementation is very well done by the government, so it is very satisfying, but become less effective.In this case, there are no factors that are included in this criterion.

a. Based on the interview with the janitor, the main roads as main roads of Tomohon-Manado and shopping area get waste collection services every day. In addition, for the main roads getting street sweeping service every day. Besides, the main roads get sweeping service every day, so the hygiene conditions in the main street is quite clean (E1).

b. The balance between the number of people served by the number of personnel or the janitor is very needed in waste management. In addition, the ability of personnel to provide waste services already very good(E13).

This suggests that the expectations and wishes of the people of the waste management system in the solid waste employees, janitors, garbage transportation officials, and communities to be prioritized by government are in Quadrant A, namely:

1) The condition of temporary solid waste locationis unclean, thus affecting the performance of the transport of waste. From the observation of the sanitary condition in the field are still found condition of temporary solid waste location that is unclean, which was indicated by the amount of garbage strewn outside the temporary solid waste location.

2) The number of temporary solid waste location based on field observation, has not been evenly spread in each location, only found in a few areas only.

3) Garbage collection time-based on field observation, is implemented 2-3 days, except for the shoppingareas which is done every day. In addition, there are still many people who do not get regular garbage collection service.

4) The numbers of janitor, from the interviews in the residential area, mostly just doing garbage collection in protocol streets and most places with a rotation system. This condition caused no garbage collectors of government official that specifically deal with waste from the settlements.

5) The response to public's complaints is a form of service to the community in order to improve the performance of waste management, so as to cater to the maximum needs of government responsiveness in serving the complaint.

\section{III.2. Community's Participation Level in Waste Management}

\section{Identification of Community's Participation Level}

Formulating a strategy to increase community's participation insolid waste managementactivities, carried outby reviewingthe parametersincludethe parametersof community participation, community actionparameters, theparametersmotivation, andsocial responsibility inthe implementation ofsolid waste management. With the scoring analysis of the four variablesis obtained the result in Table 2.

Table 2. Public's Participation Level in Solid Waste Management

\begin{tabular}{clll}
\hline No. & \multicolumn{1}{c}{ Parameter } & Score & $\begin{array}{l}\text { Participation Level based on the } \\
\text { Chougill's Ladder }\end{array}$ \\
\hline 1. & Indicator of Community's Participation & 1.68 & Conspirator \\
2. & Indicator of Community's Action & 3.12 & Conciliation \\
3. & Indicator of Community's Motivation & 2.00 & Informing \\
4. & Indicator of Community's Responsibility & 1.86 & Informing \\
\hline & Average & $\mathbf{2 . 1 6}$ & Diplomation \\
\hline
\end{tabular}

Based on Table 2 tabulation, the role of the publicis at the phase of conspiracy (1.68) as the phase of rejection, that the community has not been willing to play an active role in waste management, community's actionis at the phase of reconcile (3.12) or supported the empowerment of the clean-up activities and partnerships to waste management, community's motivation is at the phase of information (2.00) or at the phase of manipulation, that isstill pretending, diplomacy, and only limited in the information of waste management, so it does not have a strong motivation to participate in waste management, and community's responsibility is at the phase of manipulation (1.68), which is still pretending, diplomacy, and is not responsible in assisting the government to waste management.

\section{Constraints for Community's Participation in Waste Management}

Determiningthe strategies for improving the participation, then the first step is to know theparticipation's constraint itself. From the previous analysis, based on the theory thatreview the types of participation constraint, can be seen somepoints about participation constraint. This technique is based on the process of collecting and filtering knowledge from the collection of the experts through the filling ofquestionnaires with controlling opinion as feedback (Sukmawati, 2009). On this research, Delphi analysis is carried out directly on 4 (four) participation variables, each of which is the cause of the internal and external of the community. 
Tabulation of the level of community's participation can be seen in Table 3 .

Table 3. Community's Participation Level in Waste Management System

\begin{tabular}{|c|c|c|}
\hline No. & Participation Level & Participation Constraints \\
\hline 1. & $\begin{array}{l}\text { Community's participation } \\
\text { indicator }\end{array}$ & $\begin{array}{l}\text { - Lack of methods and techniques of participation. } \\
\text { - Lack of governmental access in improving public's participation to sort solid wastes } \\
\text { in its sources. }\end{array}$ \\
\hline 2. & $\begin{array}{l}\text { Community's action } \\
\text { indicator }\end{array}$ & $\begin{array}{l}\text { - Number of people who expect cleanliness activities. } \\
\text { - Lack of the governmental access for public's participation under synergistic } \\
\text { cooperation in sanitation activities. }\end{array}$ \\
\hline 3. & $\begin{array}{l}\text { Community's motivation } \\
\text { indicator }\end{array}$ & $\begin{array}{l}\text { - People are not organized well and not have sufficient motivation yet to engage } \\
\text { productively in the decision-making process. } \\
\text { - Legal instruments are not set explicitly yet about how, where and who is involved in } \\
\text { solid wastes management }\end{array}$ \\
\hline 4. & $\begin{array}{l}\text { Community's } \\
\text { responsibility indicator }\end{array}$ & $\begin{array}{l}\text { - People are not organized well and not have sufficient capacity to engage in } \\
\text { productively actions. } \\
\text { - Lack of governmental access in implementing any wastes management processes } \\
\text { based on community participation. }\end{array}$ \\
\hline
\end{tabular}

\section{Strategy to Improve Public's Participation.}

In the study of community's participation in the management of waste, the use of triangulationanalysis isapplied to draw a conclusion from the three concepts that werecombined into one.These three concepts have equal substance associated with efforts to increase community's participation in waste management.

\section{a. Literature Study}

Adi and Isbandi, (2008) mention the solutionsthat could be implemented to overcome the constraints of participation, so that community engagement can work well. 1) It takes a legal instrument which regulates substantively community's involvement, so that the mechanism becomes clear; 2) Keep the openness and accountability of government that is sensitive to the public'simportance, and 3) community needs to come together in an organized and independent medium that can be used as a channel of participation. Through an organized and independent association people can develop a vision and mission to be submitted to the government as inputs in formulating policies and waste management as well as the power to exercise control over the implementation of policies and product policies that favor the importance of the people or not.

\section{b. Previous research}

Herawatty's research (2006) revealed several strategies for improving public's participation:

1) To increase community initiatives, Herrawati (2006) suggestedcontinuous empowerment strategy that is planned and organized by the government to encourage people to be able to develop the initiative.

2) To increase public financing, the recommended strategy is to encourage people to apply for funding to the government for the maintenance of the weighing scale.

3) To improve community's decision-making, strategy suggested is to strengthen the position of social capital in the community and also emphasizes on the facilitator to constantly remind people of the importance of their role in making decisions.

4) To improve or maintain the ability to mobilize personnel, the recommended strategy is to establish a fair sanction to the people who are not actively involved in mobilizing manpower, revive community's organizations as a means to mobilize power.

5) To improve the ability to solve problems, the recommended strategy is the need for technical guidelines that provide guidance for all parties'importance in participating in the form of rights, obligations, and sanctions for violations in participating.

c. Empirical conditions

The discussion review of the extent of community's participation in waste management in Tomohon, obtained the level of community's participation to theintegrated activity of Waste Management Program and the empirical conditions of community's participation in the implementation of the program based on the following indicators:

1) Indicator of Community's Participation. Level of community's participation in community's participation parameter indicates the level of conspiracy. In order for community's participation can be optimal, people have to manage waste in their homes by packing waste and separate wet and dry waste or organic and inorganic waste, so collector officer is more efficient in terms of time. The problems identified are lack of mastery of the methods and techniques of participation by the public, so people need to be trained more often in similar activities.

2) Indicator of Community Action. Level of community's participation in community's action parameter indicates the level to reconcile. This is indicated by the presence of some of the decisions that can be taken by the public. For some examples of household waste management system based on the principle of $3 \mathrm{R}$ community through waste segregation is a paradigmatic solution; the solutions of the paradigm of how to manage waste. From the paradigm of "trash" that in practice only removing waste, to be "manage waste" in the sense of the sort to be used in practice can significantly reduce the disposal of waste. 
3) Indicator of Community's Motivation. The level of community's participation of the community's motivation showed the level of information. At this phase, the community has participated well. The problem identified is the lack of motivation of people to participate actively in the activities of waste management, and the government is still not able to put people as the subject of the construction thataligned with government.

4) Indicator of Community's Responsibility. Level of community's participation in the implementation of community's responsibility shows the level of information. Problems occurred the same with community's motivation, where people are less motivated to participate productively. Also the position of the people who have not been fully placed as the subject of development in full by the government.

\section{III.3. Relationship Between Community Perception and it's Participation in the Waste Management}

Result of statistical analysis shows that community perception $(\mathrm{X})$ is significantly correlated with community participation $(\mathrm{r}=0.983)$. It can be stated that "community's perception" is positively related to "community's participation" in wastes management.

Table 4. Results of Product-Moment Correlation Analysis

\begin{tabular}{ll}
\hline Variable & Community's perception $(\mathbf{X})$ \\
\hline Community's participation $(\mathrm{Y})$ & $\mathrm{r}=0,983 ;\left(\mathrm{r}^{2}\right)=0.966$ \\
\hline
\end{tabular}

The considerable contribution of the correlation between the factor of public's perception to the factor of community's participation in waste management as directed by the product moment correlation result that can be justified theoretically. According toWibowo and Djajawinata (2004) without the participation of the community, all waste management programs that have been planned will be in vain. One of community approaches to support government programs to be successfull is to familiarize the public to the behavior that support waste management program; to change public's perception of waste management orderly, smoothly and evenly, to change people's habit in poor waste management and local social, structure and culture factors.

Hadi (2004) stated that good waste management would bring good influence on all parties, on the workers, leaders or the results of their work. For example, in terms of quality, participation or community's involvement are important as inputs to decision making / policy; strategy to gain support from the community so as credibility in taking a decision would be better; communication that the government has a responsibility to hold opinions, aspirations and public concern; and the media of problem solvingto reduce tensions and resolve conflicts to gain consensus.

The ideas from the experts above suggest that with the change in waste management will result in the addition or enhancement of professionalism and make work more enjoyable. Changingmeans waste is no longer an issue for government alone, but it becomes a problem for all. Therefore,the awareness and cooperation between government and community are really needed.

\section{Conclusion}

1. Factors that get top priority in the improvement of solid wastes management system are (1) lack of cleanliness in the site of wastes collection, it causes negative impacts on performance of wastes transport, (2) there are fewer wastes collection sites, it causes any solid wastes are scattered around the sites, (3) time garbage collection, which is done 2-3 days interval, it causes any solid wastes are accumulated beyond the site capacity, (4) there are fewer wastes janitor, it causes the hygiene activities are only done on the urban main roads, these activities cannot reach to the settlement areas, and (5) public complaints should be followed-up by the government in improving performance of wastes management system.

2. Community participation in solid wastes management system:

a. Community's participation is on the phase of conspiracy (1.68), the urban community has not yet played an active role in solid wastes management. Community should be optimized to manage waste in their homes by packaging waste and separating wet and dry waste or organic and inorganic waste, so that the collector officials can work more efficient in terms of time.

b. Community's action is on the phase of reconcile (3.12) or support the empowerment of the clean-up activities and partnerships towards sustainable solid wastes management. It is indicated by the presence of some public decision making involving urban community.

c. Community's motivation is on the phase of information (2.00) or manipulation phase which is still pretending, diplomacy, and only limited access to the informations of solid wastes management. It results in the lower motivation of urban community to participate actively in any wastes management activities.

d. Community responsibility are on the phase of information (1.86) or manipulation phase that is pretending, diplomacy, and not fully yet assist the government in managing solid wastes. The urban community is unable to participate productively in solving any problems of domestic solid wastes.

3. The participation of urban community in wastes management is determined by its perception $(r=0.983)$. It confirms that any efforts to raise public participation should be started by improving public perceptions. 


\section{Acknowledgements}

The Author is grateful and thankful to the respondents who were interviewed in this study, for the opportunity that has been given to the writer to visit all the houses along theresearch of the performance of waste management based on public's perception.

\section{Journal Papers:}

\section{References}

[1] Aryenti. 2011. Peningkatan Partisipasi Masyarakat Dalam Pengelolaan Sampah Dengan Cara 3R (Reduce, Reuse, Recycle) di Lingkungan Permukiman Ditinjau Dari Segi Sosial Ekonomi Masyarakat. Jurnal Permukiman, Vol. 6, No. 2, pp. 75-83. www.jurnal.usu.ac.id/ index.php/persos/article.

[2] Chougill, M.B.G. 1996. A letter of Community Participation for Underdevelopment Countries, Habitat Intl, Vol.20; No.3; pp.431-444.

[3] Drackner M. 2005. An anthropological perspective on garbage. Waste Management and Research $23: 175-181$.

[4] Ehrampoush, M.H., M.B. Mogahadam. 2005. Survey of knowledge, attitude and practice of Yazd University of Medical Sciences students about solid wastes disposal and recycling. Iranian J. Env. Health Sci Eng.,2(2):26-30.

[5] Hartanto W., H. Wahyono, W.P. Tyas, 2009. Kinerja Pengelolaan Sampah di Kota Gombong Kabupaten Kebumen.Jurnal Tata Kota dan Daerah, Vol. 1, No. 1, pp. 24-29.http://eprints.undip.ac.id/15948.

[6] Himawanto D.A., D. Dhewanggap, Indarto, H. Saptoadi, dan T.A. Rohmat, 2010. Pengolahan Sampah Kota Terseleksi Menjadi Refused Derived Fuel Sebagai Bahan Bakar Padat Alternatif. Jurnal Teknik Industri, Vol. 11, No. 2, pp. 127-133.

[7] Isa, M.H., F.A.H. Asaari, N.A. Ramli, S. Ahmad, T.S. Siew, 2005. Solid waste collection and recycling in Nibong, Tebal, Penang, Malaysia: a case study. Waste Managt \& Res., 23(6): 565-570.

[8] Katonika K., 2009. What is an Integrated Waste Management Plan (IWMP)?. Tribal Waste Journal, Issue7,EPA53O-N-09-002.www.epa.gov/tribalmsw.

[9] Kitcharoen, K. 2004. The Importance-Performance Analysis Of Service Quality In Administrative Departments Of Private Universities In Thailand. ABAC Journal Vol. 24.No. 3. pp. 20-46. http://www.journal.au.edu/abac_journal/2004/sep04/ajvol24n3_article3.pdf

[10] Leuhery L., 2011. Kajian Keandalan Pola Penanggulangan Sampah Padat : Studi Kasus pada Kota Balikpapan-Kalimantan Timur. Jurnal Arika, Vol. 05, No. 1, pp. 17-26.

[11] Longe, E.O., O.O. Longe, E.F. Ukpebor, 2009.People's Perception On Household Solid Waste Management In Ojo Local Government Area In Nigeria, Iran. J. Environ. Health. Sci. Eng., , Vol. 6, No. 3, pp. 209-216.

[12] Longe, E.O., A.Williams,2006. A preliminary study of medical waste management in Lagos metropolis, Nigeria.Iranian J.Env.Health Sci.Eng.3(2):133-139.

[13] Nuryani S., A. Maas, N.W. Yuwono, S. Karibun, dan R.E. Kusumo. 2003. Kondisi Tanah dan Prediksi Umur Tempat Pembuangan Akhir Sampah TPA Bantar Gebang, Bekasi.Jurnal Ilmu Tanah dan Lingkungan 4. pp. 55-63. http://i-lib.ugm.ac.id/jurnal/detail.php?dataId.

[14] Praditya O., 2012. Studi Kualitatif Manajemen Pengelolaan Sampah di Kelurahan Sekaran Kota Semarang.Unnes Public Health Journal 2 (1), pp. 18-23. www.journal.unnes.ac.id/sju/ index.php/ujph

[15] Purnaini R., 2011. Wastes management planning in southern part of Tanjungpura Universit .(Perencanaan Pengelolaan Sampah di Kawasan Selatan Universitas Tanjungpura). Jurnal Teknik Sipil Untan, Vol. 11, No. 1, pp. 1-18. http://jurnal.untan.ac.id/index.php/jtsuntan/article/view/1065/1061.

[16] Saribanon N., E. Soetarto, S.H. Sutjahjo, E.G. Sa'id, dan Sumardjo. 2009. Planning of social participation in the community based domestic wastes management. (Perencanaan Sosial Partisipatif Dalam Pengelolaan Sampah Permukiman Berbasis Masyarakat)Studi Kasus di Kotamadya Jakarta Timur. Jurnal Forum Pascasarjana, Vol. 32 No. 2, pp. 145-154. http://repository.ipb.ac.id/handle/123456789/40816.

[17] Sartika I., 2010. Solid wastes management based on community participation.(Pengelolaan Sampah Berbasis Partisipasi Masyarakat) (Studi Kasus Sampah Pemukiman di Kecamatan Pasar Minggu, Jakarta, Selatan). Jurnal Administrasi Pemerintahan Daerah, Vol. II, Edisi ke 11, pp. 138-146. http://repository.ipb.ac.id/ handle/123456789/40816.

[18] Surjandari I., A. Hidayatno, dan A. Supriatna, 2009. Model Dinamis Pengelolaan Sampah Untuk Mengurangi Beban Penumpukan. Jurnal Teknik Industri, Vol. 11, No. 2, pp. 134-147.

[19] Wong, M. S., C. Fearon, and G. Philip, 2009. Evaluating E-government in Malaysia: An importance-performance grid analysis (IPA) of citizens and service providers, International Journal of Electronic Business, vol. 7, no. 2, pp. 105-129.

[20] Wong, M.S., N. Hideki, and P. George. 2011. The Use Of Importance-Performance Analysis (IPA) In Evaluating Japan's E-Government Services. Journal of Theoretical and Applied Electronic Commerce Research. ISSN 0718-1876. Electronic Version VOL 6/ISSUE 2 pp. 17-30. http://www.scielo.cl/pdf/jtaer/v6n2/art03.pdf.

[21] Yogiesti V., S. Hariyani, and F.R. Sutikno, 2010. Integrated solid wastes management base on urban community in Kediri city.(Pengelolaan Sampah Terpadu Berbasis Masyarakat Kota Kediri.Jurnal Tata Kota dan Daerah).Vol. 2, No. 2, pp. 95-102. http://tatakota.ub.ac.id/index.php/tatakota/article/view/113.

Books:

[22] Adi dan R. Isbandi. 2008. Intervention of community development in community empowerment (Intervensi Komunitas Pengembangan Masyarakat Sebagai Upaya Pemberdayaan Masyarakat), Raja Grafindo Persada, Jakarta.

[22] Hadi, S. 2004. Human and it's Environment .(Manusia dan Lingkungan).Semarang: Badan Penerbit UniversitasDiponegoro.

[23] Sudradjat R. 2006. Management of urban solid wastes: Solution of urban solid wastes problems through the integrated management and wastes processing into the electrical energy and compost. (Mengelola sampah Kota : Solusi Mengatasi Masalah SampahKota dengan Manajemen Terpadu dan Mengolahnya Menjadi Energi Listrik dan Kompos). Penebar Swadaya, Jakarta.

[24] Sugiyono, 2011. Quantitative-Qualitative Research Methode and R\&D. (Metode Penelitian Kuantitatif-Kualitatif dan R\&D). CV Alfabeta, Bandung.

[25] Supranto, J. 2006. Measurement of the level of consumer satisfaction.(Pengukuran Tingkat Kepuasan Pelanggan). Rineka Cipta Co.Ltd., Jakarta.

[26] Syafrudin, 2006. Management of urban solid wastes.(Buku ajar Pengelolaan Limbah Padat (Sampah) Perkotaan). Program Studi Teknik Lingkungan, Fakultas Teknik Undip, Semarang.

[27] Umar H., 2003. Research method of services consumer behavior. (Metode Riset Perilaku Konsumen Jasa). Ghalia Indonesia, Jakarta.

\section{Theses:}

[28] Herawatty, R. 2006. Strategi Peningkatan Partisipasi dalam Pengelolaan Jaringan Irigasi, Thesis, Magister Teknik Arsitektur, FTSP-ITS, Surabaya.

[29] Joseph H.K.Lai, Francis W.H.Yik, 2008, Perception of importance and performance of theindoor environmental quality of high-rise residential buildings.

[30] Kustiah, T. 2005.Kajian Kebijakan Pengelolaan Sanitasi Berbasis Masyarakat,Pusat Penelitian dan Pengembangan Permukiman, Badan Penelitian danPengembangan Departemen Pekerjaan Umum, Bandung.

[31] Sukmawati, D. 2008. Model Pemberdayaan Sampah pada Pengolahan Persampahan di Kelurahan Kutisari Surabaya.Tesis Magister Teknik Arsitektur yang tidak dipublikasikan, FTSP-ITS, Surabaya.

Chapters in Books:

[32] Page-Bucci, H., (2003). The value of Likert scales in measuring attitudes of online learners. http://www.hkadesigns.co.uk/websites/msc/reme/likert.htm.

[33] Uebersax J.S., (2006). Likert scales: dispelling the confusion. Statistical methods for rater agreement. http://ourworld.compuserve.com/homepages/jsuebersax/likert2.htm.

[34] Wibowo,A.danD.T.Djajawinata.2004.Integrated Management of Urban Solid Wastes. (Penanganan Sampah Perkotaan Terpadu).www.kkpi.go.id. 